\title{
Spatiotemporal variations of live coral cover in the northern Mesoamerican Reef System, Yucatan Peninsula, Mexico
}

\author{
Linda M. Barranco ${ }^{1}$, José D. Carriquiry ${ }^{1}$, Fabián A. Rodríguez-Zaragoza ${ }^{2}$, \\ Amílcar L. Cupul-Magaña ${ }^{3}$, Julio A. Villaescusa ${ }^{1}$, Luis E. Calderón-Aguilera ${ }^{4}$ \\ ${ }^{1}$ Instituto de Investigaciones Oceanológicas, Universidad Autónoma de Baja California, Carr. Tijuana-Ensenada Km. 107, \\ Ensenada, Baja California 22300, Mexico. E-mail: carriquiry@uabc.edu.mx \\ ${ }^{2}$ Laboratorio de Ecosistemas Marinos y Acuicultura, Departamento de Ecología, Centro Universitario de Ciencias \\ Biológicas y Agropecuarias, Universidad de Guadalajara, Carretera Guadalajara-Nogales Km 15.5, Las Agujas Nextipac, \\ Zapopan, 45110, Jalisco, Mexico. \\ ${ }^{3}$ Centro de Investigaciones Costeras. Departamento de Ciencias Biológicas, CUCosta, Universidad de Guadalajara, \\ Av. Universidad de Guadalajara 203, Del Ixtapa Puerto Vallarta, 48280, Jalisco, Mexico. \\ ${ }^{4}$ Laboratorio de Ecología y Pesquerías de la Zona Costera, Centro de Investigación Científica y de Educación Superior de \\ Ensenada. Ensenada, Baja California 22860, Mexico.
}

\begin{abstract}
Summary: Evaluating the response of coral assemblages to different disturbances is important because variations in species composition may have consequences for ecosystem functioning due to their different functional roles in coral reefs. This study evaluates changes in diversity, structure and composition of coral assemblages of the coral reefs of two national parks in the northern sector of the Mesoamerican Barrier Reef System spanning the period from 2006 to 2012, just after the impact of two hurricanes in the area. Coral assemblages in the Cancún National Park included fewer species and lower live coral coverage $(<15 \%)$ than those recorded in Cozumel. In the Cancún National Park, the species with the highest coral cover was Porites astreoides (more than $40 \%$ relative cover), and no significant temporal changes were observed in live coral cover and species composition. On the other hand, in the Cozumel National Park the dominant species were Agaricia agaricites, Siderastrea siderea and Porites astreoides, and the coral reefs showed an increase in live coral cover from $16 \%$ in 2006 to $29 \%$ in 2012. The dynamics of coral assemblages differed between the two parks: while there is an apparent stability in the current composition of the Cancún reefs, the Cozumel reefs show an increase in the abundance of the aforementioned dominant species. However, it is possible that the population characteristics of the species that dominate the coral assemblages in both national parks, such as those of fast population growth and of small colony size, do not entirely fulfill the main function of accretion and habitat heterogeneity, and more research is therefore needed to test this hypothesis.
\end{abstract}

Keywords: coral assemblages; resilience; ecosystem functioning; coral reefs; Caribbean; Mexico.

Variación espacio-temporal de la cobertura de coral del norte del Sistema Arrecifal Mesoamericano, Península de Yucatán, México

Resumen: Evaluar la respuesta de las comunidades de coral a diferentes perturbaciones es importante ya que las variaciones en la composición de las especies pueden tener consecuencias en el funcionamiento del ecosistema, debido a los diferentes roles funcionales que cada especie tiene dentro de él. En este estudio se evaluaron los cambios en la diversidad, estructura y composición de las comunidades en los arrecifes de dos Parques Nacionales ubicados en el sector norte del Sistema Arrecifal Mesoamericano, durante el periodo 2006-2012, justo después del impacto de dos huracanes en la zona. En el Parque Nacional Cancún se registraron pocas especies de coral y una cobertura de coral vivo baja $(<15 \%)$ sin cambios temporales significativos; la especie más dominante en este parque fue Porites astreoides con más del $40 \%$ de cobertura relativa. Por otro lado, los arrecifes de coral del Parque Nacional de Cozumel mostraron un incremento en la cobertura de coral del 16\% en 2006 a $29 \%$ en 2012; las especies dominantes, y que incrementaron su cobertura en este periodo, fueron Agaricia agaricites, Siderastrea siderea y $P$. astreoides. Aunque la dinámica de las comunidades de coral fue diferente en ambos parques, es posible que las características poblacionales de las especies que dominan las comunidades de coral en todos los arrecifes no cumplan por completo con las funciones principales de acreción y heterogeneidad de hábitat; sin embargo se necesita más investigación para poder evaluar esta hipótesis.

Palabras clave: comunidades de coral; resiliencia; funcionamiento del ecosistema; arrecifes de coral; Caribe; México.

Citation/Como citar este artículo: Barranco L.M., Carriquiry J.D., Rodríguez-Zaragoza F.A., Cupul-Magaña A.L., Villaescusa J.A., Calderón-Aguilera L.E. 2016. Spatiotemporal variations of live coral cover in the northern Mesoamerican Reef System, Yucatan Peninsula, Mexico. Sci. Mar. 80(2): 143-150. doi: http://dx.doi.org/10.3989/scimar.04294.23A

Editor: J. Garrabou. 
Received: June 16, 2015. Accepted: February 26, 2016. Published: May 23, 2016.

Copyright: (C) 2016 CSIC. This is an open-access article distributed under the Creative Commons Attribution-Non Commercial Lisence (by-nc) Spain 3.0.

\section{INTRODUCTION}

The increasing degradation of coral reefs is a global concern (Gardner et al. 2003). These ecosystems have been severely impacted by natural and anthropogenic disturbances causing the loss of live coral cover (LCC) (Hughes et al. 2003, Bellwood et al. 2004). Particularly in the Caribbean, LCC has decreased by $80 \%$ since the 1980s (Gardner et al. 2003), resulting in phase changes and/or stable alternative states represented by an increase in coverage of other benthic components, such as fleshy algae and sponges (Norström et al. 2009). Usually, the condition of reef health is evaluated by monitoring these changes at community level of the benthos, but the change in abundance is only one aspect of coral assemblages. These assemblages also change in their structure, composition and species richness (Aronson et al. 2002).

Variations at assemblage level are important because the species have different ecological roles in the ecosystem. For example, species with branching (e.g. Acropora palmata) or massive growth (Orbicella spp.) support the functions of structural complexity and accretion, which in turn promote the stability and diversity of other species in these ecosystems (Aronson and Precht 2001, Rodríguez-Zaragoza and Arias-González 2015). It is possible that changes in the abundance of some key species have consequences in the architectural complexity of coral reefs and thus in the ecosystem functioning, even if the overall coral cover remains stable (Green et al. 2008, Álvarez-Filip et al. 2011). Therefore, a long-term evaluation is essential in order to better understand the natural population dynamics (West and Salm 2003), how species respond to natural and anthropogenic stresses (Hughes et al. 2003) and, indirectly, the resistance and resilience of coral reef ecosystems through the evaluation of their functional groups (Bellwood et al. 2004, Petchey and Gaston 2006). Long-term studies of these variations help us to evaluate and develop conservation and management strategies aimed at protecting key species (Rodríguez-Zaragoza and Arias-González 2015).

Most studies focusing on the community structure and assemblage composition of corals in the Mesoamerican Reef System (MRS) have been short in space and/or time (e.g. Álvarez-Filip et al. 2009, Carriquiry et al. 2013, Rodríguez-Zaragoza and Arias-González 2015). In this study, we evaluate the changes in diversity, structure and composition of coral assemblages during the period from 2006 to 2012, shortly after two Category 5 hurricanes (Emily and Wilma) hit the area in 2005. We therefore had an opportunity to assess the response of coral assemblages to two large physical disturbances. Additionally, in this study we monitored eleven reefs distributed in two Natural Protected Areas (NPAs) in the northern sector of the MRS, namely the "Parque
Nacional de la Costa Occidental de Isla Mujeres, Punta Cancún y Punta Nizuc (PNIMCN)" (hereinafter Cancún National Park or simply Cancún) and the "Parque Nacional Arrecifes de Cozumel (PNAC)" (hereinafter Cozumel National Park or simply Cozumel). Different recreational activities are allowed in these parks to promote economic development in the area (Reyes-Bonilla et al. 2012). Both Cancún and Cozumel are the top tourist destination areas of the Mexican Caribbean, representing a significant economic benefit for Mexico (Ardisson et al. 2011). Thus, management and conservation of the coral reefs of these two national parks is of great ecological and economic importance.

\section{MATERIALS AND METHODS}

\section{Study area}

Five coral reef sites distributed within three polygons that encompass the Cancún National Park and six others spread over the Cozumel National Park were evaluated (Fig. 1). There are clear differences in the geomorphology of these reefs. The coral reefs of Cozumel are structurally complex, reach greater depths, have higher coral species richness and LCC, and have greater diversity of habitats (Jordán-Dahlgren and Rodríguez-Martínez 2003, Ardisson et al. 2011). In contrast, the coral reefs of Cancún are shallow and discontinuous formations (Núñez-Lara et al. 2005) with fewer coral species (Carriquiry et al. 2013).

In general, the area is influenced by the Yucatan Current, which flows from the south and passes through the Yucatan Channel. The annual average sea surface temperature is $27.9^{\circ} \mathrm{C}$, ranging from $29.0^{\circ} \mathrm{C}$ in summer to $26.0^{\circ} \mathrm{C}$ in winter (Carricart-Ganivet 2004). The average weather conditions are characterized by three periods: i) a dry season from February to May, ii) a rainy season from June to September, when tropical storms and hurricanes develop, and iii) a period of winter rain called "Nortes" from October to February (Díaz-Ruiz et al. 1998).

\section{Live coral cover database}

LCC was recorded at each site with five linear transects in Cancún and six in Cozumel (30 m long) parallel to the coast and placed randomly on the area of the crest and front reef. We used the Intercept Point Method to obtain the LCC and the rest of the benthic components. Using this method, we recorded the species of hermatypic coral to the lowest possible taxon every $25 \mathrm{~cm}$ along the transect (i.e. 120 dots per transect) (Almada-Villela et al. 2003). The surveys were made between July and September, from 2006 to 2012 (except 2008 in the Cancún), totalling 150 transects in Cancún and 252 transects in Cozumel. 

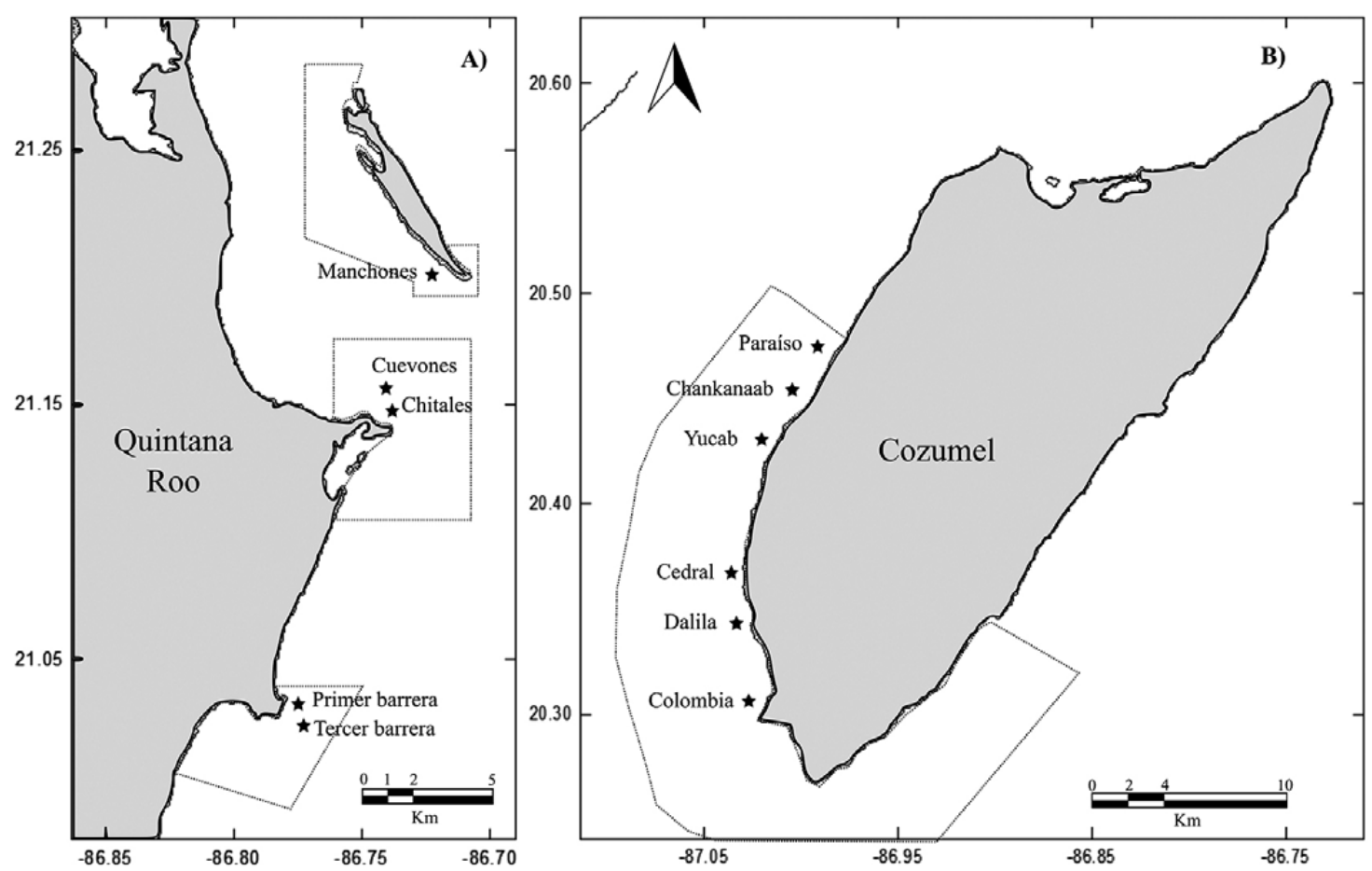

Fig. 1. - Study area. A, Yucatan Peninsula; B, Cozumel Island. The continuous line delimits the polygons of Cancún National Park and Cozumel National Park. The dots represent the sampled sites.

\section{Data analysis}

In order to check whether the sampling effort was representative in each NPA and year, species accumulation curves and non-parametric procedures such as Chao 2, Jackknife 1 and Jackknife 2 were performed as estimators of expected richness (Gotelli and Colwell 2011) from 10000 random combinations without replacement (Estimates V.9.1, Colwell 2013).

Analyses of non-metric multidimensional scaling (NMDS) were used to determine the similarity of coral assemblages among sampling sites and years for each NPA (Clarke and Warwick 2001). Prior to analysis, the data were square-root transformed to reduce the bias by the most abundant species so that the similarities depended not only on these but also on the less common species. Similarity matrices were constructed using the Bray-Curtis coefficient (Clarke and Warwick 2001). Two-way non-parametric permutational multivariate analyses of variance (PERMANOVA), using crossed factors and fixed effects, were performed to test the spatial and temporal changes in the composition and coverage of coral assemblages. The general linear model constructed was

$$
Y=\mu+\text { site }_{i}+\text { year }_{j}+\text { site }_{i} \times \text { year }_{j}+\varepsilon_{i j}
$$

where $Y$ is the variability across the set of observations; $\mu$ is the average value of the observations; site $_{i}$ is the fixed factor that represents the five sites at Cancún National Park or the six sites at the Cozumel National Park; year $_{j}$ is the fixed factor corresponding to the seven years of sampling (except 2008 in Cancún); site $_{i} \times$ year $_{j}$ is the interaction term that exists between the two fac- tors; and $\varepsilon_{i j}$ is the accumulated error of model. All the PERMANOVAS were calculated with a type III sum of square (Anderson et al. 2008). Statistical significance was tested with 10000 permutations under a reduced model. The contribution of the species per site and year were estimated with a similarity percentage analysis (SIMPER) (Clarke and Warwick 2001). Both methods were run in the PRIMER v6.1 and PERMANOVA+ program (Plymouth Marine Lab. UK).

Coral diversity was estimated from the average species richness (S), LCC (\%), the Shannon diversity (H', nits), Pielou evenness (J') and Simpson dominance $(\lambda)$ (Clarke and Warwick 2001). Analyses of variance (ANOVA) based on permutations were used to test spatial and temporal variation of these indices following the experimental design of Equation 1, because parametric assumptions were not met. These ANOVA designs were performed with Euclidian distance matrices following the criteria of Anderson et al. (2008). Finally, the percentage of change from 2006 to 2012 was calculated as the difference in the average LCC.

\section{RESULTS}

A total of 38 species of hermatypic corals belonging to 20 genera and 11 families were recorded altogether in the two NPAs. Of these, 22 species were in Cancún and 36 in Cozumel (Tables S1 and S2 in supplementary material). Only two species, Acropora palmata (Lamarck 1816) and A. prolifera (Lamarck 1816), were not recorded in Cozumel. Based on the cumulative curves, we were able to find $77 \%$ of the species richness expected for Cancún and $85 \%$ for Cozumel. The maximum ex- 
146 - L.M. Barranco et al.

Table 1. - Summary of two-way crossed factors and fixed effects ANOVAs and PERMANOVA of the coral assemblages and diversity index of Cancún National Park and Cozumel National Park. Statistical significant results $(\mathrm{p}<0.05)$ are indicated in bold.

\begin{tabular}{|c|c|c|c|c|c|}
\hline \multirow[b]{2}{*}{ Analysis } & \multirow[b]{2}{*}{ Factors } & \multicolumn{2}{|c|}{ Cancún } & \multicolumn{2}{|c|}{ Cozumel } \\
\hline & & Pseudo-F & $\mathrm{P}($ perm $)$ & Pseudo-F & $\mathrm{P}($ perm $)$ \\
\hline \multirow[t]{3}{*}{ Permutational based ANOVA } & Site & 12.11 & 0.0001 & 10.07 & 0.0001 \\
\hline & Year & 1.85 & 0.0031 & 9.90 & 0.0001 \\
\hline & Site $\times$ Year & 1.16 & 0.1180 & 1.48 & 0.0001 \\
\hline \multirow[t]{3}{*}{ Number of species (S) } & Site & 1.99 & 0.0723 & 17.29 & 0.0001 \\
\hline & Year & 1.56 & 0.1454 & 32.72 & 0.0001 \\
\hline & SitexYear & 1.24 & 0.2027 & 1.32 & 0.0858 \\
\hline \multirow[t]{3}{*}{ Shannon diversity (H') } & Site & 0.91 & 0.4818 & 8.29 & 0.0001 \\
\hline & Year & 1.10 & 0.3585 & 17.21 & 0.0001 \\
\hline & SitexYear & 1.12 & 0.3074 & 1.08 & 0.3123 \\
\hline \multirow[t]{3}{*}{ Pielou evenness (J') } & Site & 0.69 & 0.6373 & 6.74 & 0.0001 \\
\hline & Year & 1.56 & 0.1560 & 1.32 & 0.1313 \\
\hline & SitexYear & 0.66 & 0.9128 & 0.76 & 0.9862 \\
\hline \multirow[t]{3}{*}{ Simpson dominance $(\lambda)$} & Site & 1.10 & 0.3434 & 4.61 & 0.0001 \\
\hline & Year & 1.37 & 0.2270 & 17.08 & 0.0001 \\
\hline & SitexYear & 0.98 & 0.4998 & 0.91 & 0.6343 \\
\hline \multirow[t]{3}{*}{ Live coral cover $(\%)$} & Site & 8.72 & 0.0001 & 33.21 & 0.0001 \\
\hline & Year & 0.57 & 0.8383 & 44.56 & 0.0001 \\
\hline & Site $\times$ Year & 0.60 & 0.9801 & 2.28 & 0.0001 \\
\hline
\end{tabular}

pected richness was 31 species for Cancún and 46 for Cozumel (Jackknife 2). Inventories higher than $70 \%$ were achieved in most years, except for 2007 (64.29\%) and $2009(63.34 \%)$ at Cozumel, with an observed richness of 27 (2007) and 26 (2009) species. The maximum expected richnesses for these years were 42 (Chao 2) and 41 (Jackknife 2) species, respectively.

\section{Cancún National Coral Reef Park (PNIMCN)}

Reefs in the Cancún National Park had low total LCC that varied significantly between sites but not between years or in the interaction between the two factors (Table 1, Fig. 2). Spatial differences mainly originated from the first barrier (with the lowest coverage: $4.72 \% \pm 2.52$ ) and the third barrier (with the highest coverage: $13.68 \% \pm 6.54$ ) of Punta Nizuc; they were significantly different from other reefs and from each other (Fig. 2A). Though differences between years were not statistically significant, a decrease in coral cover was observed in Chitales $(-0.52 \% \pm 4.83)$ and the third barrier $(-4.78 \% \pm 7.79)$ from 2006 to 2012 (Fig. 3A). It is important to mention that the change in the third barrier was caused by a $7.85 \%$ decrease in the cover of Acropora palmata. PERMANOVA results showed that coral assemblages varied significantly between sites and years, but the interaction between the two factors was not significant (Table 1, Fig. 4A).

The pair-wise comparisons at site level showed significant differences between the five reefs studied; Cuevones and the first and third barrier of Punta Nizuc were the most dissimilar ( $>60 \%)$. Based on the SIMPER analysis, Porites astreoides (Lamarck, 1816) contributed over $40 \%$ to the structure of assemblages at the Manchones, Cuevones and Chitales reefs. At the first and third barrier of Punta Nizuc, species that contributed the highest percentage to the assemblage structure were Orbicella annularis (Ellis, 1786) (37\%) and A. palmata $(42.4 \%)$ respectively, with $P$. astreoides as the second most abundant species in these reefs. Moreover, the temporal variability of coral assemblages was
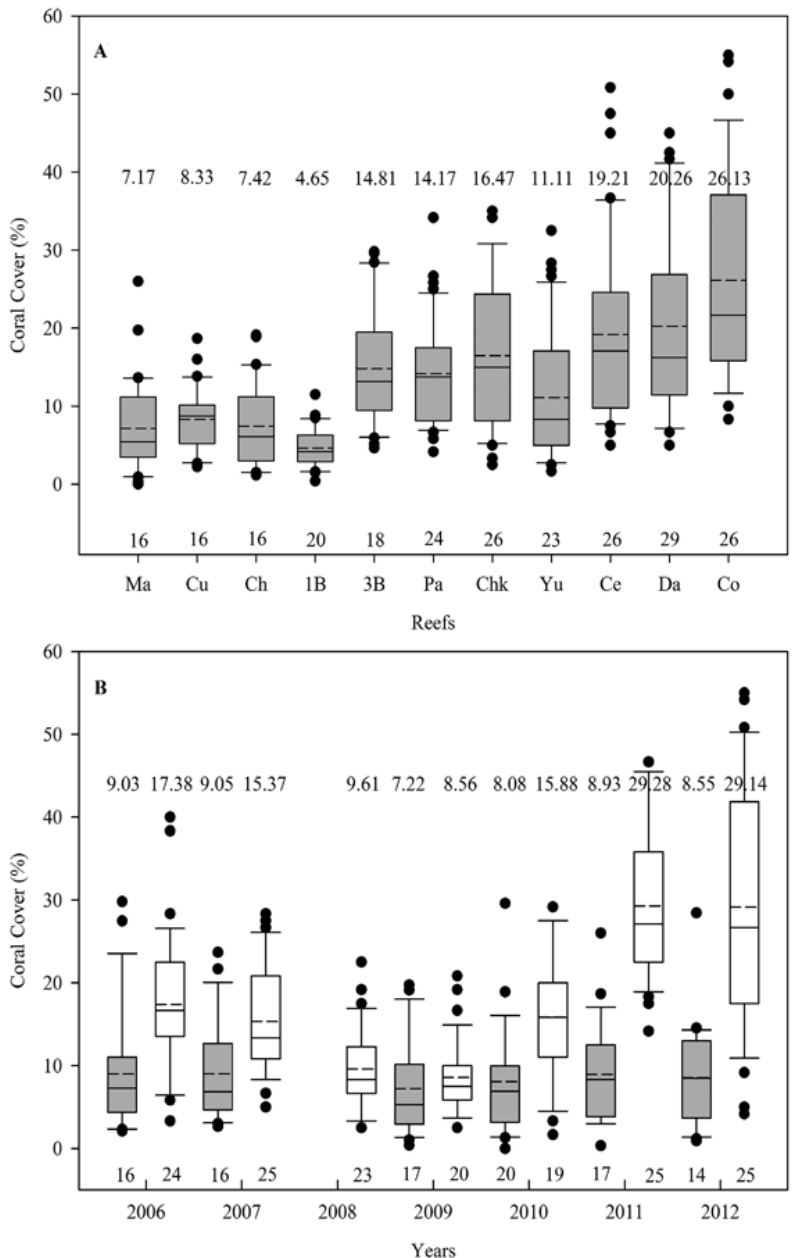

Fig. 2. - Box plot of live coral cover by reef site (A) and year (B) for Cancún and Cozumel. The solid line in the box represents the median; the dotted line represents the average. The bottom and top bars in the boxes represent the $25^{\text {th }}$ and $75^{\text {th }}$ percentiles; whiskers above and below the box are the $10^{\text {th }}$ and $90^{\text {th }}$ percentiles, respectively. The dots represent the outliers. The numbers above the boxes are the values of the average coral cover and the base the total number of species. 

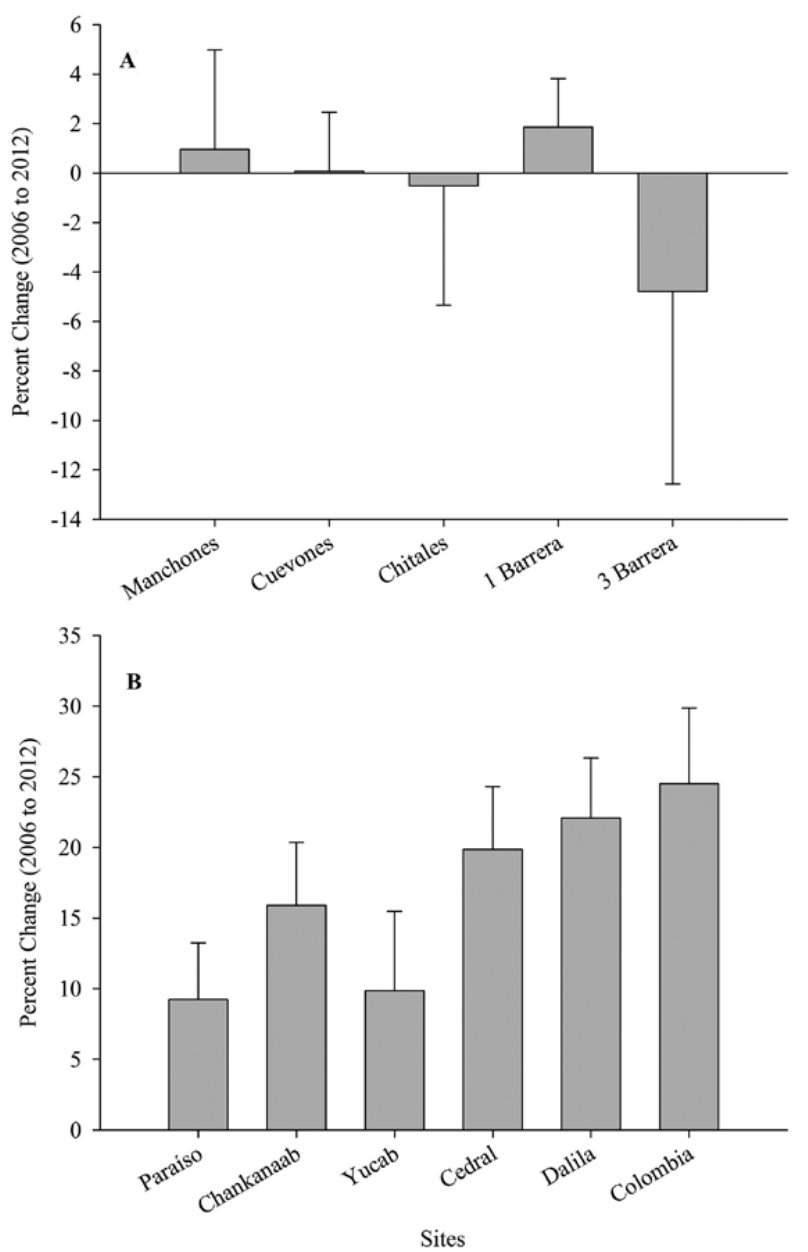

Fig. 3. - Coral cover percentage change from 2006 to $2012( \pm$ SE) of the studied reefs at Cancún (A) and Cozumel (B).

significantly different between the pairs of years 2006 vs 2007, 2007 vs 2009 and 2011 vs 2012. Based on the SIMPER analysis, changes from 2006 to 2009 were characterized by an increase in the abundance of $P$. astreoides and $P$. porites (Pallas, 1766), whereas change from 2011 to 2012 were characterized by a decrease in the abundance of $A$. palmata, $P$. astreoides, $P$. porites and Siderastrea siderea (Ellis, 1786).

As for the analysis of diversity, no significant differences between sites, years or the interaction of the two factors were detected in any of the estimated indexes: average number of species $(S)$, Shannon diversity $\left(\mathrm{H}^{\prime}\right)$, evenness $(\mathrm{J}$ ') and dominance $(\lambda)$ (Table $1)$. The average number of species was between four and five per transect in these reefs. The diversity estimated was between $H^{\prime}=0.99( \pm 0.34)$ and $H^{\prime}=1.22$ $( \pm 0.50)$. The evenness index value was from $\mathrm{J}^{\prime}=0.69$ $( \pm 0.18)$ to $J^{\prime}=0.76( \pm 0.15)$, suggesting a tendency to become more dominated by one coral species. Finally, the dominance value was between $\lambda=0.48( \pm 0.18)$ and $\lambda=0.40( \pm 0.21)$ (Supplementary Material Table S3).

\section{Cozumel National Coral Reef Park (PNAC)}

For the Cozumel National Park, the LCC changed significantly between sites, years and the interaction of

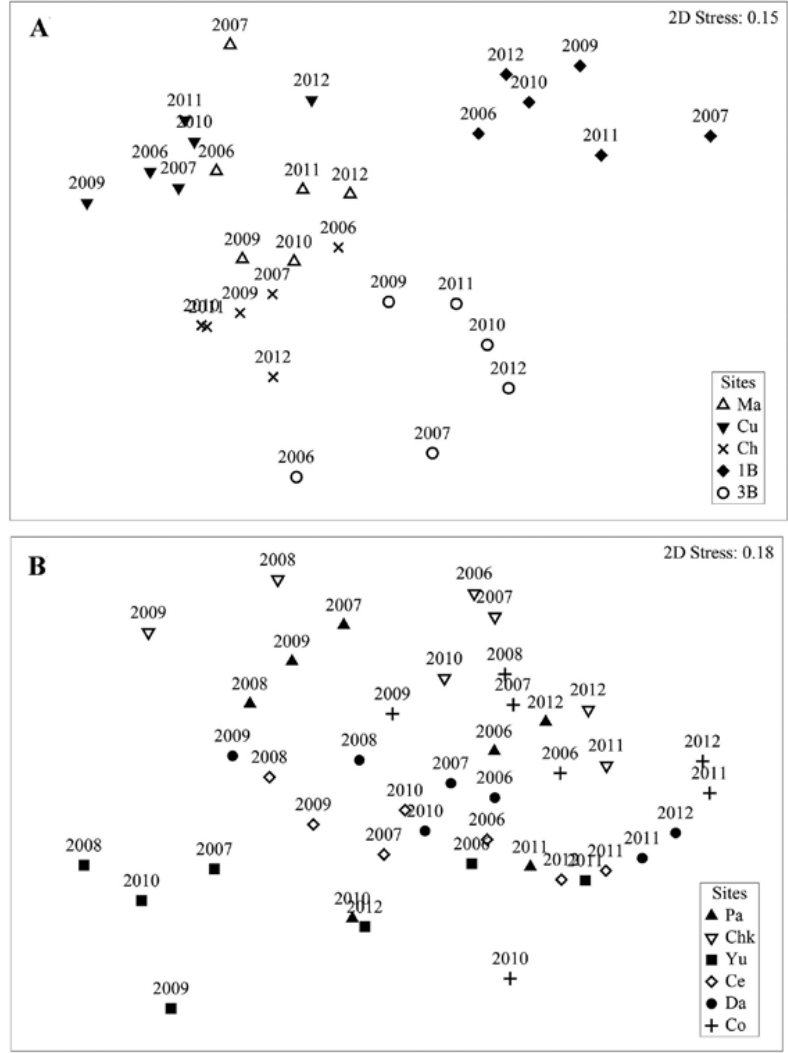

Fig. 4. - NMDS results displaying the similarity of coral assemblages at Cancún (A) and Cozumel (B) during the period 2006-2012. Ma, Manchones; $\mathrm{Cu}$, Cuevones; $\mathrm{Ch}$, Chitales; $\mathrm{B}$, primer barrera; 3B, tercer barrera; Pa, Paraíso; Chk, Chankanaab; Yu, Yucab; Ce, Cedral; Da, Dalila and Co, Colombia.

the two factors (Table 1, Fig. 2B). At a spatial scale, the same trend was observed in all sampling years: reefs located north of Cozumel (i.e. Paraíso, Chankanaab and Yucab) had a lower LCC than the southern reefs (i.e. Cedral, Dalila and Colombia) (Table S3, Fig. 2A). At a temporal scale, two types of trends occurred in all reefs: LCC decreased from 2006 to 2009, being significant only between 2007 and 2008; and also, starting from 2009 LCC increased to $29.14 \%( \pm 12.73)$ in 2012 , with significant differences between years, except for 2011 vs 2012 (Fig. 2B). The change in LCC from 2006 to 2012 was characterized by an increasing gradient from north to south, with a higher recovery in Cedral, Dalila and Colombia (Fig. 3B). This increase was determined by the species of the genera Agaricia spp., Porites spp. and Siderastrea spp.

The structure of coral assemblages was significantly different between sites, years and the interaction of the two factors (Table 1); this is shown in the NMDS in which major changes were observed between the sites over the years (Fig. 4B). In the pair-wise test of the term site*year interaction, temporal changes of coral assemblages in each reef were significant from 2009 in Paraíso, Chankanaab and Colombia and from 2010 in Yucab, Cedral and Dalila. These changes were mainly characterized by the increase in the abundance of the species Agaricia agaricites (Linnaeus, 1758), Porites astreoides, $P$. porites and Siderastrea siderea. Particularly in the Colombia reef, changes in the cover 
of Orbicella annularis, O. faveolata (Ellis, 1786) and Agaricia tenuifolia (Dana, 1848) determined the observed dissimilarities. With regard to spatial changes, significant differences were detected in 2006 between the reefs located north of the island (i.e. Paraíso, Chankanaab and Yucab) and those to the south (i.e. Cedral, Dalila and Colombia); in the remaining years, the differences between the reefs to the north and south were not evident. At all sites during the seven years of sampling, the species Agaricia agaricites showed the highest LCC (Table S2). This species, together with Siderastrea siderea, $P$. astreoides and $P$. porites contributed more than $50 \%$ of the coral cover assemblages. At a spatial level, the greatest dissimilarities between sites $(>60 \%)$ started in 2008, particularly within the Yucab reef, which showed the lowest values of LCC $(11.11 \pm 8.81 \%)$.

Finally, the analyses of diversity structure showed significant differences between sites and years, but not in the interaction between the two factors. The observed differences were in the number of species, Shannon diversity and Simpson dominance. Significant differences in the evenness index were detected only at site level (Table 1). Spatially, the number of species and Shannon diversity showed a similar trend: lower values on the reefs to the north of the island (i.e. Paraíso, Chankanaab and Yucab) than on those to the south (i.e. Cedral, Dalila and Colombia). The lowest values for both indices were recorded in the Yucab reef while the highest were recorded in the Colombia reef (Table S3). The evenness index showed an inverse trend: relatively higher values at the north of the island decreasing towards the south; however these values were between $\mathrm{J}^{\prime}=0.91( \pm 0.06)$ in Paraíso and $\mathrm{J}^{\prime}=0.85( \pm 0.09)$ in Dalila, reflecting a high evenness in the structure of assemblages in the Cozumel National Park. This finding is reinforced by the relatively low values in the dominance index, which were between $0.22( \pm 0.06)$ in Colombia and $0.28( \pm 0.12)$ in Yucab (Table S3). Two types of temporal trends were observed in both the number of species and Shannon diversity: a decreasing trend between from 2006 to 2009 and an increasing trend from 2009 to 2012 (Table S3). The lowest values were observed in 2009, with $5.35( \pm 1.85)$ species per transect and $H^{\prime}=1.45( \pm 0.34)$, while the highest were observed in 2012, with 11.04 $( \pm 4.43)$ species and $H^{\prime}=2.04( \pm 0.34)$. Evenness values ranged from $0.87( \pm 0.09)$ to $0.90( \pm 0.08)$, but no clear temporal trend was observed. The dominance index values observed were between $0.17( \pm 0.06)$ in 2012 and $0.29( \pm 0.13)$ in 2010, with an inverse trend in the number of species and the Shannon index (Table S3). The pair-wise comparisons for all indexes showed no significant difference in the early years until 2010 (except 2007 vs 2008), while from 2010 to 2012 changes were statistically significant.

\section{DISCUSSION}

The coral species richness recorded in our study (a total of 38 species) represents $74 \%$ of total species reported for reefs in Cozumel (51 species) (Fenner 1999).
This apparently low representation can be explained by the sampling strategies employed. While sampling in this study was restricted to the crest and front reef area (usually 1-10 m deep), the species richness reported by Fenner (1999) is a taxonomic list comprising several sampling areas at different depths (up to $30 \mathrm{~m}$ ) during more than a decade of studies; no single study has been able to record all those species in their surveys. In other studies where only the reef crest was sampled, only 21 (Fenner 1988) to 23 species (Álvarez-Filip et al. 2009) were reported; therefore, both sampling effort and the number of species recorded in this study were representative of the area.

In Cancún National Park LCC was low $(<15 \%)$ and no significant changes were observed during the sampling period. At the assemblage level, $P$. astreoides contributed more than $40 \%$ of the relative cover and was the most dominant species except in the reefs of Punta Nizuc, where $O$. annularis (in the first barrier) and $A$. palmata (in the third barrier) contributed $\sim 40 \%$ (Table S1). However, in the late 1980s, A. palmata was the most important species in this area. On the Chitales reef, located at Punta Cancún, monospecific patches and large colonies (1.5 m high) have been reported (Jordán-Dahlgren and Rodríguez-Martínez 1998). For 1999-2000, after the 1998 global beaching event, Rodríguez-Zaragoza and Arias-González (2015) reported that coral assemblages at Punta Nizuc were dominated by A. palmata, Siderastrea spp. and Pseudodiploria strigosa (Dana, 1848), but there are no published data for other reefs in this park. Finally, the most recent surveys carried out between 2006 and 2012 (this study) indicate that fast-growing species that form small colonies (e.g. P. astreoides) dominate the assemblages, coinciding with similar reports elsewhere in the Caribbean (Green et al. 2008, Álvarez-Filip et al. 2013). Additionally, the high dominance of only two species is reflected in the evenness and dominance index, without showing significant spatial or temporal changes.

The presence of the genus Acropora spp. in Cancún National Park is of particular importance. The species A. palamata is a key structural component that contributes significantly to the reef accretion and development of the structural framework in these reefs (Rodríguez-Zaragoza and Arias-González 2015) and also provides habitats for a wide variety of species (Precht et al. 2002). Given their importance and apparent vulnerability to perturbations, both $A$. palmata and A. cervicornis are subject to special protection under national regulations (NOM-059-SEMARNAT-2010). However, their decline of up to $50 \%$ in relative cover from 2006 to 2012 in the third barrier at Punta Nizuc (from $15.5 \%$ to $7.65 \%$, Table $\mathrm{S} 1$ ) requires special attention from the park authorities. The populations of these species are susceptible to fragmentation by physical impacts caused by the inappropriate use of anchors from tourist boats, by diving activities (Reyes-Bonilla et al. 2012) and by the effect of storms and hurricanes (Hughes and Connell 1999). In national parks, the regulations prohibit the use of anchors within the protected area, but recreational activities such as snorkelling and scuba diving are widespread and very difficult 
to control (Tratalos and Austin 2001). Although the fragmentation of colonies can promote asexual reproduction, especially in the species of branched forms (Aronson and Precht 2001), recent studies suggest that fragmentation may also facilitate the outbreak of diseases (Lamb et al. 2014). Finally, an additional cause of the decline in cover of Acropora spp. is the erosion of beach areas, previously restored through a governmental programme, which were lost to the passing of hurricane "Wilma" in 2005 (McField et al. 2008). The third barrier of Punta Nizuc seems to have the best conditions of the Cancún National Park, based on higher LCC, species richness and cover of A. palmata. Thus, implementing strategies of protection and recovery of all reefs within the park should be a priority.

The coral reefs of Cozumel showed a period of apparent recovery in LCC. In 2012, on average, LCC $(29.14 \pm 14.15 \%)$ was $25 \%$ greater than the cover that had been reported in 2005, before the passage of hurricanes Emily and Wilma (Álvarez-Filip et al. 2009). The initial decreasing trend in LCC from 2006 to 2009 may have been due to the cumulative effect of the impact of two hurricanes (Álvarez-Filip et al. 2009), which left exposed a large area of abiotic components such as sand, rubble and bare rock (Álvarez del Castillo-Cárdenas et al. 2008, Carriquiry et al. 2013). The increase in LCC from 2009 to 2012 may have resulted in part from the survival and growth of the coral fragments broken during the storms (Gardner et al. 2005), especially since there was newly available substrate for the establishment and settlement of other species (Lugo et al. 2000), and particularly for the branched, foliose or finger forms that are more susceptible to physical shock, whose subsequent fragmentation becomes an important form of asexual reproduction (Aronson and Precht 2001). An increase in the relative cover of the more abundant species was observed in the reefs of Cozumel, especially Colombia reef. The species with the greatest increase from 2006 to 2012 were A. tenuifolia (foliose growth) and $P$. porites (digitiform growth) (Table S2).

The dominant species were $A$. agaricites, $S$. siderea and $P$. astreoides. These species have already been reported as the most abundant before the hurricanes of 2005 (Álvarez-Filip et al. 2009). In the reefs of Cozumel, species richness and the contribution of more than two species to $50 \%$ of the assemblage is reflected in the diversity index, with higher values than those reported for reefs at Cancún. However, it is important to note that the most abundant species are characterized by a high population change and small colonies (Darling et al. 2012). In terms of ecological roles, these species could not fulfil the functions of accretion and heterogeneity of habitat that are provided by massive or branched colonies (e.g. Orbicella spp., Acropora palmata). Therefore, the direction of change in the structure of species assemblages towards smaller colonies and reduced structural complexity could affect the ecosystem functioning (Álvarez-Filip et al. 2011, Álvarez-Filip et al. 2013, Perry et al. 2014).

Although the reefs appear to show the same general pattern of change in the coral assemblages, multivariate analyses reveal that the assemblages on each reef exhibit different patterns of temporal variation in terms of their composition and structure. This can be evaluated by other factors acting at the regional level (i.e. evolutionary and geological history, ocean transport and larval connectivity, and reef landscape configuration) or the local level (e.g. intensity and frequency of storms, environmental gradients, habitat specialization and intra-, inter-specific interactions) (Somerfield et al. 2008).

In summary, although seven years is a relatively short period of time, two different dynamics in the structure and composition of coral assemblages were observed after the strong impact of the physical disturbance caused by two hurricanes. In Cancún (PNIMCN), coral reefs maintained a low LCC and low richness, diversity and evenness during the study period, with a significative change only in the abundance of Acropora spp. in the third barrier of Punta Nizuc. In Cozumel (PNAC), the coral reefs were characterized by an increase in LCC and high richness, diversity and evenness, with Porites spp. and Agaricia spp. showing the most significant increases. However, the question remains whether dominant species, such as those forming small colonies, carry out functions of accretion and provide heterogeneity of habitats of these ecosystems, and thus potentially limiting the performance of these ecosystems in terms of resistance and resilience to future disturbances.

\section{ACKNOWLEDGEMENTS}

We thank the "Comisión Nacional para el Conocimiento y uso de la Biodiversidad (CONABIO)" for funding the project GM006. We thank the "Comisión Nacional de Áreas Naturales Protegidas (SEMARNAT-CONANP)" and the PNIMCN authorities: Dr. Jaime González Cano, M.C. Alejandro Vega, Biol. Roberto Ibarra and M.C. Arturo González. We thank the PNAC, especially Biol. Ricardo Gómez Lozano, M.C. Christopher González and Biol. Nallely Hernández. We thank the staff and park rangers of both NPAs for providing information and logistical support. Finally, we thank Jorge Cortés and an anonymous reviewer for their comments and suggestions, which improved this manuscript. LMBS received a doctoral scholarship support from CONACYT (\#246914).

\section{REFERENCES}

Almada-Villela P.C., Sale P.F., Gold-Bouchot G., et al. 2003. Manual de métodos para el programa de monitoreo sinóptico del SAM. Doc. Téc. SAM No. 4. Belice. 149 pp.

Álvarez del Castillo-Cárdenas P.A., Reyes-Bonilla H., ÁlvarezFilip L., et al. 2008. Cozumel Island, México: A disturbance history. Proc. 11th Int. Coral Reef Symp. 18: 701-705.

Álvarez-Filip L., Millet-Encalada M., Reyes-Bonilla H. 2009. Impact of hurricanes Emily and Wilma on the coral community of Cozumel Island, Mexico. Bull. Mar. Sci. 84: 295-306.

Álvarez-Filip L., Dulvy N.K., Côté I.M., et al. 2011. Coral identity underpins architectural complexity on Caribbean reefs. Ecol. Appl. 21: 2223-2231. http://dx.doi.org/10.1890/10-1563.1

Álvarez-Filip L., Carricart-Ganivet J.P., Horta-Puga G., et al. 2013. Shifts in coral-assemblage composition do not ensure persistence of reef functionality. Sci. Rep. 3: 3486. http://dx.doi.org/10.1038/srep03486 
Anderson M.J., Gorley R.N., Clarke K.R. 2008. PERMANOVA+ for PRIMER: Guide to software and statistical methods. PRIMER-E. Plymouth, UK

Ardisson P.L., May-kú M.A., Herrera-Dorantes M.T., et al. 2011. The Mesoamerican Barrier Reef System-Mexico: consideration for its designation as a particularly sensitive sea area. Hidrobiológica 21: 261-280.

Aronson R.B., Precht W.F. 2001. White-band disease and the changing face of Caribbean coral reefs. Hydrobiologia. 460: 25-38. http://dx.doi.org/10.1023/A:1013103928980

Aronson R.B., Macintyre I.G., Precht W.F., et al. 2002. The expanding scale of species turnover events on coral reefs in Belize. Ecol. Monogr. 72: 233-249.

http://dx.doi.org/10.1890/0012-9615(2002)072[0233:TESOST 12.0.CO;2

Bellwood D.R., Hughes T.P., Folke C., et al. 2004. Confronting the coral reef crisis. Nature 429: 827-833. http://dx.doi.org/10.1038/nature02691

Carricart-Ganivet J.P. 2004. Sea surface temperature and the growth of the West Atlantic reef-building coral Montastraea annularis. J. Exp. Mar. Biol. Ecol. 302: 249-260. http://dx.doi.org/10.1016/j.jembe.2003.10.015

Carriquiry J., Barranco L., Villaescusa J., et al. 2013. Conservation and Sustainability of Mexican Caribbean Coral Reefs and the Threats of a Human-Induced Phase-Shift. In: Silvern S., Young S. (eds), Environmental Change and Sustainability. InTech, pp. 29-51.

Clarke K.R., Warwick R.M. 2001. Change in marine communities: An approach to statistical analysis and interpretation. PRIMERE_Plymouth.

Colwell R. 2013. EstimateS: Statistical estimation of species richness and shared species from samples.V.9. Retrieved from http://purl.oclc.org/estimates

Darling E.S., Álvarez-Filip L., Oliver T.A., et al. 2012. Evaluating life-history strategies of reef corals from species traits. Ecol. Lett. 15: 1378-1386. http://dx.doi.org/10.1111/j.1461-0248.2012.01861.x

Díaz-Ruiz S., Aguirre-León A., Arias-González J.E. 1998. Habitat interdependence in coral reef ecosystems: a case study in a Mexican Caribbean reef. Aquat. Ecosyst. Health. 1: 387-397. http://dx.doi.org/10.1016/S1463-4988(98)00026-8

Fenner D. 1988. Some leeward reefs and corals of Cozumel, Mexico. Bull. Mar. Sci. 42: 133-144.

Fenner D. 1999. New observations on the stony coral (Scleractinia, Milleporidae and Stylasteridae) species of Belize (Central America) and Cozumel (Mexico). Bull. Mar. Sci. 64: 143-154.

Gardner T.A, Côté I.M., Gill J.A., et al. 2003. Long-term regionwide declines in Caribbean corals. Science 301: 958-960. http://dx.doi.org/10.1126/science. 1086050

Gardner T.A., Gill J.A., Grant A., et al. 2005. Hurricanes and Caribbean coral reefs: immediate impacts, recovery trajectories and contribution to long-term decline. Ecology 86: 174-184. http://dx.doi.org/10.1890/04-0141

Gotelli N., Colwell R. 2011. Estimating species richness. In: Magurran A.E., McGill B. (eds), Biological Diversity. Frontiers in Measurement and Assessment. Oxford University Press. pp. 39-54.

Green D.H., Edmunds P.J., Carpenter R.C. 2008. Increasing relative abundance of Porites astreoides on Caribbean reefs mediated by an overall decline in coral cover. Mar. Ecol. Prog. Ser. 359: $1-10$. http://dx.doi.org/10.3354/meps07454

Hughes T.P., Connell J.H. 1999. Multiple stressors on coral reefs: A long-term perspective. Limnol. Oceanogr. 44 (3 part 2): 932-940. http://dx.doi.org/10.4319/10.1999.44.3 part 2.0932

Hughes T.P., Baird A.H., Bellwood D.R., et al. 2003. Climate change, human impacts, and the resilience of coral reefs. Science 301: 929-933. http://dx.doi.org/10.1126/science.1085046

Jordán-Dahlgren E., Rodríguez-Martínez R.E. 1998. Post-hurricane initial recovery of Acropora palmata in two reefs of the Yucatán Peninsula, México. Bull. Mar. Sci. 63: 213-228.

Jordán-Dahlgren E., Rodríguez-Martínez R.E. 2003. The Atlantic coral reefs of Mexico. In: Cortés J. (ed.), Latin American Coral
Reefs. Elsevier, pp. 131-158.

http://dx.doi.org/10.1016/B978-044451388-5/50007-2

Lamb J.B., True J.D., Piromvaragorn S., et al. 2014. Scuba diving damage and intensity of tourist activities increases coral disease prevalence. Biol. Conserv. 178: 88-96. http://dx.doi.org/10.1016/j.biocon.2014.06.027

Lugo A.E., Rogers C.S., Nixon S.W. 2000. Hurricanes, Coral Reefs and Rainforests: Resistance, Ruin and Recovery in the Caribbean. AMBIO 29: 106-114. http://dx.doi.org/10.1579/0044-7447-29.2.106

McField M., Bood N., Fonseca A., et al. 2008. Status of the Mesoamerican Reef after the 2005 coral bleaching event. In: Wilkinson C., Souter D. (eds), Status of Caribbean coral reefs after bleaching and hurricanes in 2005. Global Coral Reef Monitoring Network and Reef and Rainforest Research Center, pp. 45-60.

Norström A., Nyström M., Lokrantz J., et al. 2009. Alternative states on coral reefs: beyond coral-macroalgal phase shifts. Mar. Ecol. Prog. Ser. 376: 295-306. http://dx.doi.org/10.3354/meps07815

Núñez-Lara E., Arias-González J.E., Legendre P. 2005. Spatial patterns of Yucatan reef fish communities: Testing models using a multi-scale survey design. J. Exp. Mar. Biol. Ecol. 324: 157-169. http://dx.doi.org/10.1016/j.jembe.2005.04.011

Perry C.T., Steneck R.S., Murphy G.N., et al. 2014. Regional-scale dominance of non-framework building corals on Caribbean reefs affects carbonate production and future reef growth. Glob. Chang. Biol. 21: 1153-1164. http://dx.doi.org/10.1111/gcb.12792

Petchey O.L., Gaston K.J. 2006. Functional diversity: back to basics and looking forward. Ecol. Lett. 9: 741-758. http://dx.doi.org/10.1111/j.1461-0248.2006.00924.x

Precht W.F., Bruckner A.W., Aronson R.B., et al. 2002. Endangered acroporid corals of the Caribbean. Coral Reefs 21: 41-42. http://dx.doi.org/10.1007/s00338-001-0209-2

Reyes-Bonilla H., Cupul-Magaña A.L., Loreto-Viruel R.M., et al. 2012. Evaluación de la capacidad de carga para buceo en áreas naturales protegidas del mar Caribe y el golfo de California, México. In: Ivanova A., Ibáñez R. (eds), Medio Ambiente y Política Turística en México I. INE-SEMARNAT, pp. 149-162.

Rodríguez-Zaragoza F.A., Arias-González J.E. 2015. Coral biodiversity and bio-construction in the northern sector of the Mesoamerican reef system. Front. Mar. Sci. 2: 1-16. http://dx.doi.org/10.3389/fmars.2015.00013

Somerfield P.J., Jaap W.C., Clarke K.R., et al. 2008. Changes in coral reef communities among the Florida Keys, 1996-2003. Coral Reefs 27: 951-965 http://dx.doi.org/10.1007/s00338-008-0390-7

Tratalos J.A., Austin T.J. 2001. Impacts of recreational SCUBA diving on coral communities of the Caribbean island of Grand Cayman. Biol. Conserv. 102: 67-75. http://dx.doi.org/10.1016/S0006-3207(01)00085-4

West J.M., Salm R.V. 2003. Resistance and Resilience to Coral Bleaching: Implications for Coral Reef Conservation and Management. Conserv. Biol. 17: 956-967. http://dx.doi.org/10.1046/j.1523-1739.2003.02055.x

\section{SUPPLEMENTARY MATERIAL}

The following material is available through the online version of this article and at the following link:

http://www.icm.csic.es/scimar/supplm/sm04294esm.pdf

Table S1. - Mean coral cover $( \pm 1 \mathrm{SD})$ of the species recorded in the Cancún National Park.

Table S2. - Mean coral cover $( \pm 1 \mathrm{SD})$ of the species recorded in the Cozumel National Park

Table S3. - Ecological indexes of coral assemblages in Cancún National Park and Cozumel National Park as a function of locality and year. Codes: $\mathrm{S}$ is the average species richness; H' is Shannon diversity; J' is Pielou evenness; $\lambda$ is Simpson dominance; LCC is live coral cover. 


\section{Spatiotemporal variations of live coral cover in the northern Mesoamerican Reef System, Yucatan Peninsula, Mexico}

Linda M. Barranco, José D. Carriquiry, Fabián A. Rodríguez-Zaragoza,

Amílcar L. Cupul-Magaña, Julio A. Villaescusa, Luis E. Calderón-Aguilera

Supplementary material 
Table S1. - Mean coral cover $( \pm 1 \mathrm{SD})$ of the species recorded in the Cancún National Park.

\begin{tabular}{|c|c|c|c|c|c|c|}
\hline & 2006 & 2007 & 2009 & 2010 & 2011 & 2012 \\
\hline Acropora cervicornis & $0.23( \pm 0.52)$ & $0.15( \pm 0.46)$ & $0.35( \pm 0.91)$ & $0.14( \pm 0.52)$ & $0.23( \pm 0.66)$ & $0.04( \pm 0.18)$ \\
\hline Acropora palmata & $4.10( \pm 7.52)$ & $2.26( \pm 4.23)$ & $2.20( \pm 4.24)$ & $2.72( \pm 6.46)$ & $1.91( \pm 3.19)$ & $2.91( \pm 6.18)$ \\
\hline Acropora prolifera & $0.06( \pm 0.29)$ & & & $0.09( \pm 0.35)$ & $0.05( \pm 0.18)$ & $0.15( \pm 0.50)$ \\
\hline Agaricia agaricites & $0.29( \pm 0.62)$ & $0.02( \pm 0.06)$ & $0.54( \pm 1.41)$ & $0.20( \pm 0.32)$ & $0.32( \pm 0.48)$ & $0.17( \pm 0.45)$ \\
\hline Agaricia fragilis & $0.03( \pm 0.17)$ & & & & & \\
\hline Agaricia tenuifolia & & $0.75( \pm 3.27)$ & $0.10( \pm 0.42)$ & $0.09( \pm 0.34)$ & $0.21( \pm 0.73)$ & $0.28( \pm 1.03)$ \\
\hline Colpophyllia natans & & $0.06( \pm 0.30)$ & $0.10( \pm 0.35)$ & $0.35( \pm 1.32)$ & $0.16( \pm 0.80)$ & $0.62( \pm 1.82)$ \\
\hline Dichocoenia stokesii & & & & $0.02( \pm 0.09)$ & & \\
\hline Diploria labyrinthiformis & & & & $0.04( \pm 0.19)$ & & \\
\hline Favia fragum & & & $0.01( \pm 0.03)$ & & & \\
\hline Isophyllastrea rigida & & & & $0.01( \pm 0.05)$ & $0.03( \pm 0.09)$ & \\
\hline Meandrina meandrites & & & & & & $0.01( \pm 0.04)$ \\
\hline Montastrea cavernosa & $0.06( \pm 0.13)$ & $0.29( \pm 0.69)$ & $0.05( \pm 0.12)$ & $0.19( \pm 0.58)$ & $0.05( \pm 0.21)$ & $0.08( \pm 0.21)$ \\
\hline Orbicella annularis & $0.41( \pm 0.93)$ & $0.62( \pm 1.43)$ & $0.63( \pm 1.41)$ & $0.56( \pm 0.97)$ & $0.67( \pm 1.45)$ & $0.87( \pm 1.66)$ \\
\hline Orbicella faveolata & $0.12( \pm 0.35)$ & & $0.17( \pm 0.48)$ & $0.39( \pm 1.22)$ & & \\
\hline Porites astreoides & $2.33( \pm 2.26)$ & $2.33( \pm 2.62)$ & $1.70( \pm 2.46)$ & $1.82( \pm 1.92)$ & $2.93( \pm 4.09)$ & $2.16( \pm 2.57)$ \\
\hline Porites porites & $0.84( \pm 1.91)$ & $0.91( \pm 1.71)$ & $0.71( \pm 0.68)$ & $0.39( \pm 0.46)$ & $0.76( \pm 1.11)$ & $0.50( \pm 0.99)$ \\
\hline Pseudodiploria clivosa & $0.02( \pm 0.08)$ & $0.13( \pm 0.34)$ & & & $0.05( \pm 0.21)$ & \\
\hline Pseudodiploria strigosa & $0.09( \pm 0.32)$ & $0.26( \pm 0.65)$ & $0.01( \pm 0.07)$ & $0.22( \pm 0.67)$ & $0.27( \pm 0.79)$ & $0.48( \pm 1.69)$ \\
\hline Siderastrea radians & $0.04( \pm 0.10)$ & $0.24( \pm 0.40)$ & $0.03( \pm 0.08)$ & $0.01( \pm 0.04)$ & $0.03( \pm 0.09)$ & \\
\hline Siderastrea siderea & $0.23( \pm 0.47)$ & $0.71( \pm 1.91)$ & $0.46( \pm 0.95)$ & $0.38( \pm 0.66)$ & $0.56( \pm 0.77)$ & $0.25( \pm 0.79)$ \\
\hline Stephanocoenia intersepta & & $0.01( \pm 0.07)$ & $0.01( \pm 0.06)$ & $0.01( \pm 0.04)$ & & $0.03( \pm 0.11)$ \\
\hline
\end{tabular}

Table S2. - Mean coral cover $( \pm 1 \mathrm{SD})$ of the species recorded in the Cozumel National Park.

\begin{tabular}{|c|c|c|c|c|c|c|c|}
\hline & 2006 & 2007 & 2008 & 2009 & 2010 & 2011 & 2012 \\
\hline Acropora cervicornis & & $0.01( \pm 0.10)$ & $0.01( \pm 0.10)$ & & & $0.01( \pm 0.10)$ & $0.01( \pm 0.10)$ \\
\hline Agaricia agaricites & $5.16( \pm 3.19)$ & $4.91( \pm 3.22)$ & $3.72( \pm 2.61)$ & $3.06( \pm 2.36)$ & $3.82( \pm 2.97)$ & $4.97( \pm 2.92)$ & $6.82( \pm 4.25)$ \\
\hline A garicia fragilis & & & & & $0.01( \pm 0.10)$ & & $0.46( \pm 0.85)$ \\
\hline Agaricia grahamae & & & & & & & $0.02( \pm 0.14)$ \\
\hline Agaricia humilis & $0.10( \pm 0.39)$ & & $0.02( \pm 0.14)$ & $0.01( \pm 0.10)$ & $0.08( \pm 0.37)$ & $0.19( \pm 0.53)$ & $0.05( \pm 0.24)$ \\
\hline Agaricia lamarcki & $0.09( \pm 0.36)$ & $0.03( \pm 0.17)$ & $0.03( \pm 0.22)$ & $0.01( \pm 0.10)$ & $0.12( \pm 0.47)$ & $0.09( \pm 0.30)$ & $0.24( \pm 0.58)$ \\
\hline Agaricia tenuifolia & $0.32( \pm 0.68)$ & $0.30( \pm 0.69)$ & $0.35( \pm 0.70)$ & $0.53( \pm 0.93)$ & $0.29( \pm 0.69)$ & $1.08( \pm 2.20)$ & $1.90( \pm 3.41)$ \\
\hline Colpophyllia natans & $0.17( \pm 0.54)$ & $0.02( \pm 0.20)$ & $0.13( \pm 0.48)$ & $0.01( \pm 0.10)$ & $0.06( \pm 0.21)$ & $0.08( \pm 0.35)$ & $0.15( \pm 0.49)$ \\
\hline Dichocoenia stokesii & $0.05( \pm 0.24)$ & $0.07( \pm 0.23)$ & $0.01( \pm 0.10)$ & & & $0.17( \pm 0.42)$ & $0.15( \pm 0.32)$ \\
\hline Diploria labyrinthiformis & $0.15( \pm 0.38)$ & $0.17( \pm 0.46)$ & $0.08( \pm 0.32)$ & $0.08( \pm 0.29)$ & $0.12( \pm 0.29)$ & $0.17( \pm 0.50)$ & $0.22( \pm 0.50)$ \\
\hline Eusmilia fastigiata & $0.36( \pm 0.57)$ & $0.46( \pm 0.76)$ & $0.17( \pm 0.39)$ & $0.17( \pm 0.39)$ & $0.24( \pm 0.43)$ & $0.81( \pm 0.90)$ & $1.18( \pm 1.18)$ \\
\hline Favia fragum & & & $0.01( \pm 0.10)$ & $0.03( \pm 0.22)$ & & & $0.17( \pm 0.39)$ \\
\hline Isophyllastrea rigida & $0.08( \pm 0.29)$ & $0.16( \pm 0.39)$ & $0.05( \pm 0.24)$ & $0.08( \pm 0.29)$ & $0.13( \pm 0.36)$ & $0.02( \pm 0.14)$ & $0.02( \pm 0.14)$ \\
\hline Isophyllia sinuosa & & $0.01( \pm 0.10)$ & & & & & \\
\hline Leptoseris $\mathrm{Cl}$ & $0.01( \pm 0.10)$ & $0.01( \pm 0.10)$ & $0.01( \pm 0.10)$ & $0.01( \pm 0.10)$ & & & $0.01( \pm 0.10)$ \\
\hline Madracis decactis & $0.23( \pm 0.53)$ & $0.08( \pm 0.25)$ & $0.12( \pm 0.29)$ & $0.06( \pm 0.21)$ & $0.07( \pm 0.27)$ & $0.24( \pm 0.45)$ & $0.43( \pm 0.63)$ \\
\hline Madracis mirabilis & & & $0.01( \pm 0.10)$ & & & & \\
\hline Manicina areolata & & & $0.02( \pm 0.20)$ & & & $0.09( \pm 0.30)$ & \\
\hline Meandrina meandrites & $0.28( \pm 0.52)$ & $0.56( \pm 0.84)$ & $0.37( \pm 0.81)$ & $0.17( \pm 0.42)$ & $0.31( \pm 0.69)$ & $0.59( \pm 0.88)$ & $0.78( \pm 0.99)$ \\
\hline Montastrea cavernosa & $1.32( \pm 1.30)$ & $1.72( \pm 1.64)$ & $0.69( \pm 0.79)$ & $0.98( \pm 1.04)$ & $1.45( \pm 1.44)$ & $1.62( \pm 1.59)$ & $1.79( \pm 1.34)$ \\
\hline Mussa angulosa & & & & & & $0.01( \pm 0.10)$ & $0.16( \pm 0.57)$ \\
\hline Mycetophyllia lamarckiana & $0.07( \pm 0.27)$ & $0.1( \pm 0.31)$ & $0.02( \pm 0.20)$ & $0.01( \pm 0.10)$ & $0.01( \pm 0.10)$ & $0.13( \pm 0.39)$ & $0.22( \pm 0.40)$ \\
\hline Orbicella annularis & $1.02( \pm 1.85)$ & $1.3( \pm 2.30)$ & $0.27( \pm 0.84)$ & $0.14( \pm 0.59)$ & $0.23( \pm 0.64)$ & $1.62( \pm 2.64)$ & $1.72( \pm 2.56)$ \\
\hline Orbicella faveolata & $0.64( \pm 1.24)$ & $0.79( \pm 2.02)$ & $0.86( \pm 1.19)$ & $0.61( \pm 1.03)$ & $1.28( \pm 2.41)$ & $0.41( \pm 0.86)$ & $1.49( \pm 2.22)$ \\
\hline Orbicella franski & $0.02( \pm 0.14)$ & $0.09( \pm 0.09)$ & $0.02( \pm 0.14)$ & & & & \\
\hline Porites astreoides & $1.94( \pm 1.56)$ & $1.60( \pm 1.26)$ & $1.31( \pm 1.38)$ & $1.06( \pm 1.11)$ & $1.11( \pm 1.36)$ & $1.76( \pm 1.94)$ & $3.55( \pm 2.14)$ \\
\hline Porites colonensis & & & & $0.01( \pm 0.10)$ & & & \\
\hline Porites porites & $0.57( \pm 0.93)$ & $0.51( \pm 0.92)$ & $0.59( \pm 0.91)$ & $0.76( \pm 1.30)$ & $1.24( \pm 1.99)$ & $2.82( \pm 3.28)$ & $4.38( \pm 4.89)$ \\
\hline Pseudodiploria clivosa & $0.02( \pm 0.14)$ & $0.01( \pm 0.10)$ & & & & $0.03( \pm 0.17)$ & $0.07( \pm 0.27)$ \\
\hline Pseudodiploria strigosa & $0.06( \pm 0.26)$ & $0.14( \pm 0.42)$ & $0.12( \pm 0.29)$ & $0.14( \pm 0.44)$ & $0.09( \pm 0.30)$ & $0.28( \pm 0.67)$ & $0.37( \pm 0.75)$ \\
\hline Scolymia cubensis & & & & $0.02( \pm 0.10)$ & & & \\
\hline Scolymia lacera & & & & & & & $0.01( \pm 0.10)$ \\
\hline Siderastrea radians & $0.10( \pm 0.31)$ & $0.01( \pm 0.10)$ & $0.02( \pm 0.14)$ & $0.05( \pm 0.19)$ & & $0.25( \pm 0.55)$ & $0.36( \pm 0.59)$ \\
\hline Siderastrea siderea & $1.76( \pm 1.42)$ & $2.20( \pm 1.58)$ & $1.62( \pm 1.20)$ & $1.08( \pm 1.07)$ & $1.27( \pm 1.14)$ & $2.56( \pm 1.99)$ & $4.00( \pm 2.14)$ \\
\hline Solenastrea bournoni & & & & & & $0.02( \pm 0.14)$ & \\
\hline Stephanocoenia intersepta & $0.13( \pm 0.30)$ & $0.17( \pm 0.44)$ & $0.05( \pm 0.24)$ & $0.09( \pm 0.30)$ & $0.02( \pm 0.14)$ & $0.34( \pm 0.60)$ & $0.47( \pm 0.67)$ \\
\hline
\end{tabular}


Table S3. - Ecological indexes of coral assemblages in Cancún National Park and Cozumel National Park as a function of locality and year. Codes: $\mathrm{S}$ is the average species richness; H' is Shannon diversity; J' is Pielou evenness; $\lambda$ is Simpson dominance; LCC is live coral cover.

\begin{tabular}{|c|c|c|c|c|c|c|}
\hline & & $\mathrm{S}$ (per transect) & $\mathrm{H}^{\prime}(\log \mathrm{e})$ & $\mathrm{J}^{\prime}$ & $\lambda$ & $\operatorname{LCC}(\%)$ \\
\hline \multirow{5}{*}{ Cancún } & Manchones & $4.22( \pm 1.31)$ & $0.99( \pm 0.34)$ & $0.69( \pm 0.18)$ & $0.48( \pm 0.18)$ & $7.17( \pm 5.76)$ \\
\hline & Cuevones & $4.80( \pm 1.54)$ & $1.11( \pm 0.35)$ & $0.74( \pm 0.16)$ & $0.43( \pm 0.16)$ & $8.33( \pm 3.98)$ \\
\hline & Chitales & $4.43( \pm 1.30)$ & $1.06( \pm 0.30)$ & $0.74( \pm 0.16)$ & $0.44( \pm 0.15)$ & $7.42( \pm 5.27)$ \\
\hline & 1 barrier & $4.21( \pm 1.70)$ & $1.05( \pm 0.36)$ & $0.76( \pm 0.15)$ & $0.44( \pm 0.16)$ & $4.65( \pm 2.52)$ \\
\hline & 3 barrier & $5.63( \pm 2.11)$ & $1.22( \pm 0.50)$ & $0.71( \pm 0.20)$ & $0.40( \pm 0.21)$ & $14.81( \pm 6.54)$ \\
\hline \multirow{6}{*}{ Cozumel } & Paraíso & $6.90( \pm 2.59)$ & $1.68( \pm 0.37)$ & $0.91( \pm 0.06)$ & $0.23( \pm 0.09)$ & $14.17( \pm 7.09)$ \\
\hline & Chankanaab & $6.55( \pm 2.96)$ & $1.57( \pm 0.38)$ & $0.88( \pm 0.06)$ & $0.26( \pm 0.09)$ & $16.47( \pm 9.43)$ \\
\hline & Yucab & $5.64( \pm 3.07)$ & $1.47( \pm 0.46)$ & $0.92( \pm 0.06)$ & $0.28( \pm 0.12)$ & $11.11( \pm 8.81)$ \\
\hline & Cedral & $7.96( \pm 3.22)$ & $1.73( \pm 0.39)$ & $0.86( \pm 0.07)$ & $0.24( \pm 0.10)$ & $19.21( \pm 10.60)$ \\
\hline & Dalia & $7.92( \pm 3.75)$ & $1.67( \pm 0.44)$ & $0.85( \pm 0.09)$ & $0.26( \pm 0.12)$ & $20.26( \pm 11.38)$ \\
\hline & Colombia & $8.29( \pm 2.64)$ & $1.77( \pm 0.28)$ & $0.86( \pm 0.06)$ & $0.22( \pm 0.06)$ & $26.13( \pm 12.74)$ \\
\hline \multirow{6}{*}{ Cancún } & 2006 & $5.13( \pm 1.36)$ & $1.07( \pm 0.29)$ & $0.67( \pm 0.15)$ & $0.46( \pm 0.14)$ & $9.03( \pm 6.07)$ \\
\hline & 2007 & $4.30( \pm 1.26)$ & $1.10( \pm 0.34)$ & $0.78( \pm 0.17)$ & $0.41( \pm 0.16)$ & $9.05( \pm 5.90)$ \\
\hline & 2009 & $4.28( \pm 1.77)$ & $1.07( \pm 0.37)$ & $0.78( \pm 0.16)$ & $0.43( \pm 0.16)$ & $7.22( \pm 5.63)$ \\
\hline & 2010 & $5.00( \pm 2.21)$ & $1.13( \pm 0.47)$ & $0.72( \pm 0.18)$ & $0.43( \pm 0.15)$ & $8.08( \pm 6.28)$ \\
\hline & 2011 & $4.96( \pm 1.49)$ & $1.19( \pm 0.36)$ & $0.76( \pm 0.15)$ & $0.40( \pm 0.15)$ & $8.93( \pm 5.86)$ \\
\hline & 2012 & $4.22( \pm 1.68)$ & $0.94( \pm 0.41)$ & $0.67( \pm 0.19)$ & $0.51( \pm 0.20)$ & $8.55( \pm 4.57)$ \\
\hline \multirow{7}{*}{ Cozumel } & 2006 & $7.07( \pm 2.69)$ & $1.64( \pm 0.37)$ & $0.87( \pm 0.08)$ & $0.25( \pm 0.10)$ & $17.38( \pm 7.34)$ \\
\hline & 2007 & $7.06( \pm 2.09)$ & $1.67( \pm 0.30)$ & $0.87( \pm 0.06)$ & $0.24( \pm 0.08)$ & $15.37( \pm 7.05)$ \\
\hline & 2008 & $5.72( \pm 1.76)$ & $1.50( \pm 0.29)$ & $0.89( \pm 0.08)$ & $0.27( \pm 0.08)$ & $9.61( \pm 5.19)$ \\
\hline & 2009 & $5.35( \pm 1.85)$ & $1.45( \pm 0.34)$ & $0.90( \pm 0.08)$ & $0.28( \pm 0.10)$ & $8.56( \pm 5.12)$ \\
\hline & 2010 & $5.81( \pm 2.05)$ & $1.47( \pm 0.38)$ & $0.87( \pm 0.09)$ & $0.29( \pm 0.13)$ & $15.88( \pm 7.05)$ \\
\hline & 2011 & $8.44( \pm 3.70)$ & $1.78( \pm 0.44)$ & $0.88( \pm 0.06)$ & $0.22( \pm 0.10)$ & $29.28( \pm 11.38)$ \\
\hline & 2012 & $11.04( \pm 3.43)$ & $2.04( \pm 0.34)$ & $0.87( \pm 0.05)$ & $0.17( \pm 0.06)$ & $29.14( \pm 12.73)$ \\
\hline
\end{tabular}

